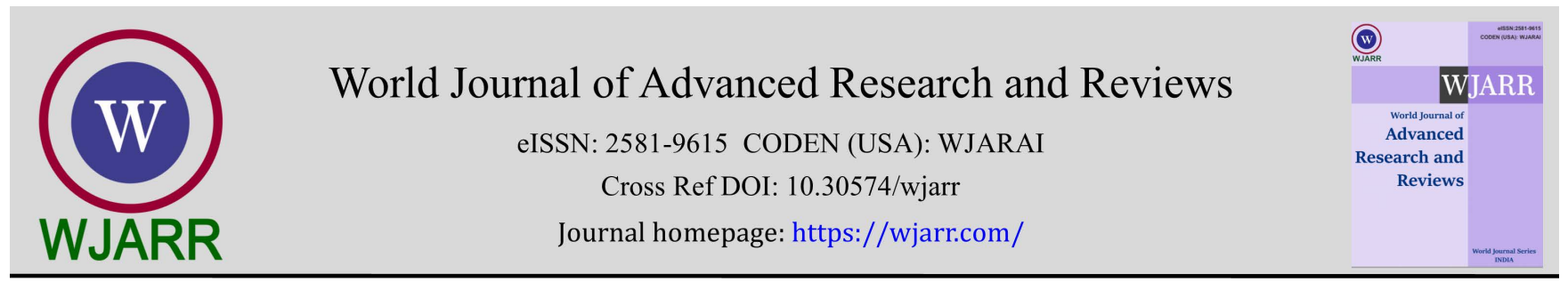

(REVIEW ARTICLE)

Check for updates

\title{
Review on coffee research and production in Nigeria in the last one decade (2009- 2018)
}

\author{
Modinat Adewunmi Alli ${ }^{*}$, Kehinde Ademola Adesanya, Mutiat Oluwaseyi Agboola-Adedoja, Adejoke \\ Adebusola Adelusi, Qudus Adebayo Ogunwolu, Chinweike Abednego Ugwu and Ayodele Oladipo Akinpelu
}

Economics and Extension, Cocoa Research Institute of Nigeria, P.M.B. 5244, Ibadan, Oyo State, Nigeria 1234567.

World Journal of Advanced Research and Reviews, 2021, 09(01), 031-036

Publication history: Received on 20 December 2020; revised on 28 December 2020; accepted on 30 December 2020

Article DOI: https://doi.org/10.30574/wjarr.2021.9.1.0501

\begin{abstract}
The study was carried out to review coffee research and production in Nigeria in the last one decade (2009-2018). The research was done through the use of some past and published works on coffee. The two economical type of coffee in Nigeria are $C$. arabica and $C$. robusta. It was discovered that the coffee producers are abandoning their coffee farms for other agricultural crops due to less production quality and international price. The study revealed a downward trend in coffee production in the last one decade. Challenges facing coffee production in Nigeria were low prices and poor farm management. Therefore, there should be more research on addressing these challenges while farmers and others stakeholders in coffee production should be motivated to establish new coffee farms.
\end{abstract}

Keywords: Coffee; Coffee production; Low price; Farm management

\section{Introduction}

Coffee story begins in Ethiopia, which is the original home of the coffee plant, Coffea arabica, which still grows wild in the forest of the highlands of Ethiopia. Coffee is discovered as a beverage plant, it is believed that its cultivation and use began as early as the ninth century in Ethiopia. [1,2]. Coffee is one of the top-traded agricultural commodities. Coffee plays a crucial role in the economies of producing countries. For instance, it was reported that the gross domestic product (GDP) largely depends on coffee export revenues with the sector employing an important proportion of the rural population [3].

At the end of the nineteenth century, the discovery of $C$. robusta in Congo opened the way for coffee growing on lowland areas [4]. Despite its significance in the world trade, marketing of coffee encountered a downward trend in the last few decades. The major challenge was due to low prices in the international market [5].and the impact of this was mainly felt by the producers. All coffee plants are classified in the large family of rubiceae. The leaves are dark green and glossy, usually $10-15 \mathrm{~cm}$ (4-6 inches) long and $6 \mathrm{~cm}$ (2.4 inches) wide, simple, entire and opposite. The flowers are axillary, and clusters of fragrant white flowers bloom simultaneously. The flowers are followed by oval berries of about $1.5 \mathrm{~cm}$ [6].when immature they are green, and they ripen to yellow, then crimson, before turning black on drying. Each berry usually contains two seeds, but 5-10 percent of the berries have only one, these are called pea berries. [7]. Arabica berries ripen in six to eight months, while Robusta takes nine to eleven months [8]. Coffee cherries are the raw fruit of the coffee plant, which are composed of two coffee beans covered by a thin parchment like hull and further surrounded by pulp. These cherries are usually harvested after 5 years of coffee trees plantation and when the bear fruit turns red [9].

\footnotetext{
* Corresponding author: Modinat Adewunmi Alli

Economics and Extension, Cocoa Research Institute of Nigeria, P.M.B. 5244, Ibadan, Oyo State, Nigeria 1234567. 
The cultivation of coffee involves removing trees from the desired plantation while some big trees are left to provide shade particularly at the young crop stage. The seedlings are then transplanted in rows of $3 \mathrm{~m} \times 3 \mathrm{~m}$ spacing using appropriate planting patterns. Site selection is determined by the types of coffee which is highly influenced among other factors [10]. Coffea species are woody, ranging from small shrubs to large. It has opposite leaves and branches and the characters of plants vary widely. Some lose their leaves at the beginning of the dry season, other keep them for three or more years. Nevertheless, the two economic species (C. arabica and C. robusta) are evergreen. The leaves range in colour from yellowish to dark green. Newly developed leaves of some varieties are bronzed, others are purple-tinged; they vary in size from $1-40 \mathrm{~cm}$ in length. $C$. liberica have the largest leaves while the cultivated coffee species have dense clusters of white fragrant flowers, some species have flower which are cream, even tinged with pink or purplish red and without fragrance. Some of the fruits have sweet pulp while others are unpalatable when ripe; they show a variety of colours from green through red and purple to black. Some are small as peas and other are as large as plum [11].

Coffee contributes largely to the economy of more than 50 countries in Asia, Latin America and Africa. [12]. It is also one of the most valuable primary products in global trade for agricultural produce. It is predominantly grown by 25 to 30 million smallholder producers in about 80 countries in the tropics $[13,14]$. Due to its pleasant, taste, aroma and health benefits [15], coffee is one of the most widely consumed beverages throughout the world. Coffee plant is categorized among medicinal plant. [16]. Beans and leaves of the coffee plant are found to have generous amount of secondary metabolites such as exters of hydroxycinamic acids, phenolic compounds and mengiferin which have high level of antioxidant properties and anti-inflammatory effects on humans $[17,18]$. Coffee is top ranked agricultural export product in Tanzania providing direct income to more than 400,000 households which support the livelihoods of some 2.5 million individuals and generate between USD 150 and 225 million per year of foreign exchange earnings [19].

According to International Coffee Organization (ICO), coffee is one of the most important commodities in the International Agricultural Trade, representing a significant source of income to several countries of Africa, Asia and Latin America. Coffee is one of the economic commodities and one of the most widely consumed beverages in the world, with about 102 million bags production in a year. Despite its importance, the value of coffee exported from Africa, including Ethiopia has declined considerably over the years due to lack of sustainability and poor competitiveness of the sub-sector at the National and International market. For instance, Africa's production fell by 18.5 percent and its share of world production fell accordingly and was down by 1.5 percent for the crop year 2008/09 and 2009/10. This is primarily ascribed to various problems, including inadequate access to improved production and processing technologies, poor market access and lack of incentives. The sub-sector is also constrained by the prevailing ineffective and inefficient policy frameworks that strongly affect the benefits obtained thereof [20]. The objective of the study is to identify the challenges facing coffee producers and also to identify the trend in the quantity of coffee between 2009 and 2018.

\section{Methodology}

A desk research was carried out using information and statistics from Food and Agricultural Organization, International Coffee Organization, Central Bank of Nigeria and Federal Department of Agriculture.

\section{Coffee Production in Nigeria}

Coffee cultivation in Nigeria dates back to early nineteenth century but its production was on a less significant commercial level. Coffee was reported to be the second major traded commodity to oil. This plays a vital role in the balance of trade between developed and developing countries [21, 22].with Nigeria having better comparative advantage in its production than some similar crops [23].

In Nigeria, $C$. arabica is grown mainly by small scale farmers in the highland area of Mambilla in Taraba State, as well as Abia, Kogi, Kwara, Ondo, and Ogun States [24]. It used to be one of the major cash crops constituting the backbone of Nigerian economy before the emergence and predominance of oil. Over 80 percent of coffee from developing countries, particularly Nigeria, is produced by small scale farmers who lack adequate technical education and are faced with low market price leading to poor management, poor productivity and abandoned farms [25,26].

The Federal Department of Agriculture (FDA) in Nigeria reported the introduction of coffee into the country as far back as 1920. However, the crop was introduced earlier as shown by export figure of 5.5tons in 1896, 25.2tons in 1909, respectively [25]. Prior to the FDA introductions, the most widely cultivated species were $C$. liberica and $C$. abeokutea, which are indigenous to Nigeria. Following the dwindling demand for the indigenous coffee other commercially important coffea species were introduced to the farmers in the 1930s.C. canephor (Robusta) and C. arabica account for 
90 percent and 4 percent, respectively of coffea export. [25]. Except for the Mambilla of Taraba state and some parts of Obudu cattle ranch in Crossriver state where C. arabica is cultivated. Nigeria is a major producer of C. canephora (Robusta), coffee is cultivated in 14 states of the federation, covering over 5000 hectares from all the introductions, the main species now cultivated in Nigeria are Robusta (94\%), Arabica (4\%) and Liberica (2\%). Hence, Nigerian coffee is a target to instant coffee market. However, Java and Quillou account for 8.5 and 15 percent respectively of cultivated Robusta. Coffee growing states are Oyo, Ogun, Ondo, Ekiti, Kwara, Kogi, Edo, Delta, Abia, Cross River, Akwa Ibom, Taraba, Bauchi and Jos. [27].

According to [22]. Kogi State is known as the major producer of coffee; especially the Robusta. Income generated from production and marketing of coffee in the state has contributed immensely to sustenance of livelihoods and development of communities. Despite all these, it was recently discovered that coffee producers have been abandoning their coffee farms for other agricultural crops. Though, the reasons for this are not properly documented. This then calls for urgent attention in order to make necessary intervention to forestall the declining trend of coffee production.

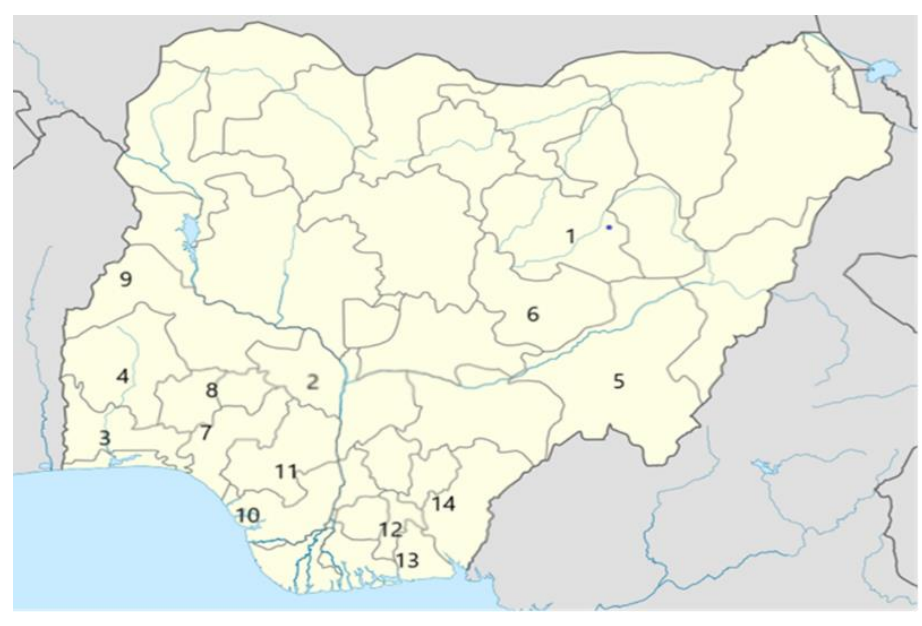

Figure 1 Map of Nigeria showing coffee growing states.

Legend: 1. Bauchi State; 2. Kogi State; 3. Ogun State; 4. Oyo State; 5. Taraba State; 6. Plateau State; 7. Ondo State; 8. Ekiti State; 9. Kwara State; 10. Delta State; 11. Edo State; 12. Abia State; 13. Akwa- Ibom State and 14. Cross-River State.

Table 1 Trend in coffee production in Nigeria

\begin{tabular}{|l|l|l|l|}
\hline Year & Area harvested (ha) & Yield & Production quantity (tons) \\
\hline 2009 & 1800 & 11333 & 2040 \\
\hline 2010 & 1990 & 12063 & 2400 \\
\hline 2011 & 1942 & 13001 & 2525 \\
\hline 2012 & 1893 & 12767 & 2417 \\
\hline 2013 & 1639 & 12811 & 2100 \\
\hline 2014 & 1596 & 12822 & 2047 \\
\hline 2015 & 1527 & 12766 & 1950 \\
\hline 2016 & 1352 & 12561 & 1698 \\
\hline 2017 & 1517 & 12513 & 1898 \\
\hline 2018 & 1483 & 12465 & 1849 \\
\hline
\end{tabular}




\section{Coffee Quality, Drink and Its Byproducts}

Coffee quality is of critical importance to the coffee industry. Coffee is a product that has desirable clean raw and roasted appearance, attractive, aroma and good cup taste. However, it is beyond dispute that in Ethiopia the quality of coffee produced by farmers has been deteriorating from time to time. Furthermore, serious complaints have been raised about the declining quality of coffee produced in different parts of the country [28]. High quality/certified coffee and organic coffee currently attracts high premium in the world market [29,30]. [31]. reported that there are different methods to evaluate coffee quality, most of them are based on a score scale of 0 to 100 , similar to the wine ratings. Score augmentations are obtained from the ratings assigned to non-standardized descriptors qualified on a smaller scale, which together give a result relative to 100 according to their quality score.

Coffee has been consumed for over one thousand years and today it is the most consumed drink in the world with more than 400 billion cups yearly [32]. Coffee is included in the context of coffee by-products as novel food because typically only roasted coffee is consumed. Nevertheless, green coffee can be marketed as such (without roasting), and an infusion from non-selective water extraction can be prepared from the chopped beans [33,34]. Coffee beans are the main yields of coffee production. There are many other beneficial by-products which are coffee cherry husk, parchment skin, silverskin and pulp. One of which is "cascara" also known as coffee cherry tea. It is derived from the dried fruit of the coffee plant, a by-product that is usually discarded after the coffee beans have been taken out. The coffee husks, peel and pulp comprise nearly 45 percent of the fruit [35].

In addition, Coffee pulp is the main by-product and it is estimated that around one ton of coffee pulp is produced during the manufacture of two tons of coffee [36]. Coffee pulp is rich in cellulose, hemicellulose, phenolic compounds, and caffeine [35]. Coffee cherry tea which is also known as the cascara has been consumed as a tea even before the roasted coffee beans we know today were discovered. Historical records suggest that Ethiopians and Yemenis made a caffeinated drink out of the fruit ever since an Ethiopian herdsman discovered the plant [37].

Cascara is a caffeinated drink, although its caffeine content is $\mathrm{kmm}$ significantly lower than a comparable amount of coffee. Moreover, cascara is a natural product and it depends on the species and geographical origin in which the coffee is produced. The caffeine content of a cascara brewed with $20 \mathrm{~g} / \mathrm{L}$ that was steeped for 10 minutes came at around 111.4 $\mathrm{mg} / \mathrm{L}$, which compared to coffee in the range of 400-800 mg/L, cascara only has around 12-25 percent the amount of caffeine as a comparable amount of coffee [38]. Technically, cascara cannot be regarded as a "tea", since it is not made from tea leaves but rather classified as herbal infusion. [39]. Annually, approximately 25 million tons of coffee cherry skin is thrown away [40].

\section{Conclusion and recommendation}

The research reviewed the production of coffee in Nigeria between 2009 and 2018. It was revealed that there are some challenges facing coffee production in Nigeria such as low market prices and poor farm management which are the reason farmers are abandoning their farms. According to the research there has been a downward trend in coffee production as a result of these challenges over the years. Thus, farmers should be motivated in establishing new coffee farms, and more research on reasons for farmers abandoning their farms should be encouraged.

\section{Compliance with ethical standards}

\section{Acknowledgments}

My sincere appreciation and thanks to my co-authors who supported me in the course of my research.

Finally, I appreciate my mentor (Dr A.O Akinpelu) for his guidance, valuable corrections and patience throughout the research.

\section{Disclosure of conflict of interest}

The authors have not declared any conflict of interest. 


\section{References}

[1] De Beenhouwer M, Muleta D, Peeters B, Van Geel M, Lievens B, Honnay O. DNA pyrosequencing evidence for large diversity differences between natural and managed coffee mycorrhizal fungal communities. Agron. Sustain. Dev. 2015; 35: 241-249.

[2] Capa D, Pérez-Esteban J, Masaguer A. Unsustainability of recommended fertilization rates for coffee monoculture due to high N20 emissions. Agron. Sustain. Dev. 2015; 35: 1551-1559.

[3] Krishnan S. Sustainable Coffee Production; Oxford University Press: Oxford, UK. 2017.

[4] Centre de coopération internationale en recherché agronomique le développement. All you need to know about coffee. Agricultural Research for Development. 2009.

[5] Osorio N. The impact of the crisis of low coffee prices. International Coffee Organization. 2005.

[6] Duke, James A. “coffea arabica L. Purdue University. 1983; Retrieved 15 December 2020.

[7] Hamon S, Noirot M, Anthony F. "Developing a coffee core collection using the principal components score strategy with quantitative data” (PDF). Core collections of Plant Genetic Resources. 1995; Retrieved 15 December 2020.

[8] Pradeepkumar T. Kumar, Pradeep Management of Horticultural Crops: 2008; Vol.11 Horticulture Science Series: In Parts. New India Publishing, 2008.

[9] Arya M, Rao JM. An impression of coffee carbohydrates. Critical Reviews in Food Science and Nutrition. 2007; 47: $51-67$.

[10] Opeke LK. Tropical commodity tree crops. Spectrum Books Ltd, Ibadan. Second edition. $2012 ; 226$.

[11] Cannell, MG. R Exploited plants: Coffee. Biologist. 1983; 30(5): 257-263.

[12] Dinesh Kumar M, Babitha J. Rates of leaf fall and nutrient recycling of shade trees in coffee (Coffea arabica L.), cardamom (Elettaria cardamomum Maton) and black pepper (Piper nigrum L.) pro-duction systems of Mudigere, Karnataka. Journal of Spices and Aromatic Crops. 19 Jan 2011; 15(2).

[13] FAO. Coffee Countries by commodities. Food and Agricultural commodities production. FAO Statistics. FAO, Rome. 2010.

[14] Orr AW, Ndhlovu M. Smallholder Coffee in Zambia: A socio-economic field report. 2005.

[15] Gebeyehu BT, Bikila SL. Determination of caffeine content and antioxidant activity of coffee. Am J Appl Chem. 31 Mar 2015; 3(2): 69-76.

[16] Eva BP, Tímea B, N'ora P Phytochemical over view and medicinal importance of coffea species from the past until now. Asian Pacific Journal of Tropical Medicine. 2016; 9: 1127-1135.

[17] Campa C, Mondolot L, Rakotondravao A, Bidel LPR, Gargadennec A, Couturon E, Fisca PL, Rakotomalala J, JayAllemand C, Davis AP. A survey of mangiferin and hydroxycinnamic acid ester accumulation in coffee (Coffea) leaves: biological implications and uses. Annals of Botany. 2012; 110: 1-19.

[18] Delaroza F, Rakocevic M, Malta GB, Sanchez PM, Bruns RE, Scarminio IS. Factorial design effects of plant density, pattern and light availability on the caffeine, chlorogenic acids, lipids, reducing sugars and ash contents of $C$. arabica L. beans and leaves. Analytical Methods 2017; 9: 3612-3618.

[19] Tanzania Coffee Board, Coffee Production, Export and Price Trends for Arusha and Kilimanjaro Region. Moshi Tanzania. 2017.

[20] International Coffee Organization, ICO Annual Review 2009; pg 37. Available from www.ico. Org.

[21] Adeleke SA, Olukunle OJ, Olaniran JA, Famuyiwa BS. Design of a small-scale hulling machine for improved wetprocessed coffee. Int. J. Sci.Technol. Res. 2017; 6(08): 392-397.

[22] Aderolu IA, Babalola FD, Ugioro O, Anagbogu CF, Ndagi I, Mokwunye FC, Mokwunye IU, Idrisu M, Asogwa EU. Production and marketing of coffee (Coffea robusta) in Kogi State, Nigeria: challenges and recommendation for intervention. J. Soc. Sci. Res. 2014; 3(2): 207-215.

[23] CBN, Central Bank of Nigeria. Domestic, production, consumption and prices. Stat. Bull. 2007; 18: 131-15.

[24] William JA. Coffee Production Manual (Hand Book) Published by Cocoa Research Institute of Nigeria (CRIN) Ibadan. 2008; 5-20. 
[25] Williams JA. Coffee Breeding in Nigeria. In: Progress in Tree Crop Research, 2nd Edition, Published by Cocoa Research Institute of Nigeria (CRIN) Ibadan. 1989; 127-140.

[26] Agbongiarhuoyi AE, Oduwole 00, Sanusi RA. Technology Transfer and Adoption of Coffee Coppicing in Kogi State, Nigeria. In; Proceeding of the 21st. International Conference on Coffee Science Organized by ASIC - Association Scientifique International Du Café; Held in Montpellier France 11 - 15th September 2006.

[27] Adepoju A, Adenuga O, Mapayi E, Olaniyi O. Coffee: Botany, Distribution, Diversity, Chemical Composition and Its Management. (IOSR-JAVS). July 2017; 10(7): 57-62.

[28] Desse Nure. Oromiya Regional State Coffee quality, major quality problems and suggested solutions (Amharic). Paper presented on the workshop on Oromiya coffee quality improvement, Sept 2003.

[29] Willer H, Lucas K. (Eds). The World of Organic Agriculture Statistics and Emerging Trends 2010. IFOAM, Bonn and FiBL Frick. 2010; 244. Retrieved 14/02/2018

[30] Ramos M, Alvarado E, Davila M, Rodriquez OR, Sanchez Y. Weed management alternatives for organic coffee agroforestry systems of Puerto Rico. 2014; Retrieved 12/02/2018

[31] Thomas E, Puget S, Valentine D, Songer P. Sensory Evaluation-Profiling and Preferences. Elsevier Inc. London 2017.

[32] Mussatto, SI, Macchado EM, Martins S, Teixeira JA. Production, composition, and application of coffee and its industrial residues. Food and Bioprocess Technology. 2011 July 1;4(5):661.

[33] Onakpoya I, Terry R, Ernst E. The use of green coffee extract as a weight loss supplement: A systematic review and meta-analysis of randomized clinical trials. Gastroent. Res. Pract. 2011.

[34] Macheiner L, Schmidt A, Schreiner M, Mayer HK. Green coffee infusion as a source of caffeine and chlorogenic acid. J. Food Compos. Anal. 2019; 84: 103-307.

[35] Esquivel P, Jiménez VM. Functional properties of coffee and coffee by-products. Food Res. Int. 2012; 46: 488-495.

[36] Alves R.C, Rodrigues F, Nunes MAA, Vinha AF, Oliveira M.B.P.P. State of the art in coffee processing by-products. In Handbook of Coffee Processing By-Products: Sustainable Applications; Galanakis, C., Ed.; Academic PressElsevier: Burlington, MA, USA, 2017; 1-26.

[37] Anonymous. What is Cascara? - Exploring Coffee Cherry Tea. (c) 2020 (cited 2020 Dec 15) Available from http://www.manualcoffeebrewing.com

[38] Zeckel S, Susanto PC, Erfiani NM. Market Potential of Cascara Tea from Catur Village Kintamani Bali. International Conference on Fundamental and Applied Research (ICFAR) 2020 March 3.

[39] Ksienryk L. Feiert kaffeekirschen-Limo ihr comeback? (c) 2018 (cited 2020 Dec 15) Available from https://nginfood.com/artikel/limonade-kaffeekirschen-selo-cascara-cate-novel-food.

[40] Ceuticals F. Future ceuticals (c) 2019 (cited 2020 Dec 15) Available from http://www.futureceuticals.com/coffeeberry.cascara. 